\title{
Decreased Repair of X-ray Induced DNA Single- Strand Breaks in Lymphocytes in Down's Syndrome
}

\author{
K. ATHANASIOU, E. G. SIDERIS, ${ }^{(20)}$ AND C. BARTSOCAS \\ Biology Division, N.R.C. "Demokritos," Aghia Paraskevi, Athens, Greece [K. A., E. G. S.], and Second Department \\ of Peciatrics, University of Athens, Athens, Greece [C. B.]
}

\section{Summary}

Gamma-ray irradiation introduces single and/or double strand breaks into the DNA molecule of the cells. In the case of mammalian cells, these breaks are being repaired in general during the first hr following exposure to ionizing radiation. The article reports on the results obtained from testing the ability of cultured lymphocytes from patients with Down's syndrome to repair radiationinduced DNA single-strand breaks. The ability to repair was deduced from the study of the DNA sedimentation profiles in alkaline sucrose gradients. It was found that lymphocytes from Down's syndrome patients are less efificient in repairing singlestrand DNA breaks than are lymphocytes from normal individuals. This significantly increased fraction of unrepaired DNA strand breaks might be associated with the unusually high level of radiation-induced chromosome aberrations as compared with normals.

\section{Speculation}

The present work was carried out to find out whether the increased frequency of dicentrics and rings observed in human lymphocytes from patients with Down's syndrome is related to the presence of a DNA single-strand break repair mechanism of reduced capacity.

Patients who exhibit chromosome abnormalities involving an extra chromosome, such as trisomy-21 or Klinefelter's syndrome (XXY), have an increased susceptibility to malignancy and to $X$ or $\gamma$-ray induced chromosomal aberrations $(12,13)$.

The observation that cultured lymphocytes, obtained from patients with Down's syndrome are twice as sensitive to the induction of chromosome dicentrics and rings by $\gamma$-rays $(13,21)$ could be an indication that a defect in the system by which genetic damage is repaired is responsible for the increased chromosomal abnormalities and risk of developing leukemia.

We studied the ability of lymphocytes from patients with Down's syndrome to repair $\gamma$-ray-induced damage by means of the DNA sedimentation profiles in alkaline sucrose gradients. It has been shown previously that mammalian cells of various origins carry mechanisms by which single or double breaks induced by ionizing radiation on the DNA molecule can be rejoined (5) and that the ability to rejoin strand breaks appears to be a general property of the rapidly dividing cells (9).

Although human cell lines obtained from individuals having different types of inherited disorders, like xeroderma pigmentosum (XP), ataxia telangiectasia, and Fanconi's anemia, were found to be associated with defects in the ability to repair certain kinds of physical or chemical damage on their DNA $(3,8,11,16,17,18)$, there is no evidence of any known human cell line capable of dividing to have a defect in their ability to rejoin single- or doublestrand breaks introduced into their DNA by X- or $\gamma$-rays (8).

It is shown by means of the DNA sedimentation profiles in alkaline sucrose gradients that cells from three patients with Down's syndrome were unable to repair $\gamma$-ray-induced, singlestrand breaks in their DNA.

\section{MATERIALS AND METHODS}

\section{CELL CULTURES}

Five $\mathrm{ml}$ of blood were obtained from normal individuals and patients with Down's syndrome (age range, 2 to 4 years) by venipuncture and transferred to heparinized tubes. The sedimentation of the red blood cells was completed following incubation of the heparinized blood at $37^{\circ} \mathrm{C}$ for $2 \mathrm{hr}$ in tubes held at a $45^{\circ}$ angle. One-half $\mathrm{ml}$ of the supernatant consisting of white blood cells and serum was transferred to culture tubes containing $1.5 \mathrm{ml}$ fetal calf serum, $4 \mathrm{ml}$ of McCoy's $5 \mathrm{~A}$ medium, and $0.01 \mathrm{ml}$ of Sigma phytohemagglutinin. After gentle mixing, the cultures were left for incubation at $37^{\circ} \mathrm{C}$ for $72 \mathrm{hr}$.

\section{LABELING}

The cells were labeled by adding $\left[{ }^{3} \mathrm{H}\right]$ thymidine $(1 \mu \mathrm{Ci} / \mathrm{ml})$ in the culture medium during the last $24 \mathrm{hr}$ of incubation.

\section{$\gamma$-IRRADIATION}

The tubes were centrifuged at $1500 \mathrm{rpm}$ for $5 \mathrm{~min}$, and the supernatant was removed. They were then placed on ice and were irradiated in a Gammacell 200 (Atomic Energy of Canada, Ltd.) with 16,000 rads. One lot of the tubes, after resuspension of the pellet in cultural medium, was left for repair incubation at $37^{\circ} \mathrm{C}$ for $1 \mathrm{hr}$, whereas the cells from the remaining tubes were immediately harvested.

\section{REPAIR INCUBATION AND ULTRACENTRIFUGATION}

Pellets of cells harvested either immediately after irradiation or following repair incubation for $1 \mathrm{hr}$ were resuspended in $0.2 \mathrm{ml}$ of $0.02 \%$ EDTA in Dulbecco's A buffered solution, and $0.2 \mathrm{ml}$ of this suspension was pipetted smoothly onto a lysis layer on top of alkaline sucrose gradients. The lysis buffer consisted of $0.2 \mathrm{ml}$ of $2 \%$ sodium dodecyl sulfate and $0.02 \mathrm{M}$ EDTA, and the gradients were 5 to $20 \%$ sucrose gradients in $0.1 \mathrm{NaOH}: 0.1 \mathrm{M} \mathrm{NaCl}$. Following lysis, tubes in a SW 50.1 rotor (Beckman Instruments Inc.) were loaded into a L5-75 Spinco ultracentrifuge (Beckman Instruments, Inc., Spinco Div.) and spun at 38,000 rpm for $60 \mathrm{~min}$ at $20^{\circ} \mathrm{C}$.

\section{RADIOACTIVITY COUNTING}

Following centrifugation, the tubes were punctured at the bottom with a syringe needle, and seven-drop fractions were collected with the aid of a peristaltic pump (Perpex 10200) into absorptive paper strips (2). For this purpose, Whatman 311 paper strips 1.5- 
$\mathrm{cm}$ wide divided into sections of $2.0-\mathrm{cm}$ long were used. The strips were placed in $5 \%$ trichloroacetic acid for $10 \mathrm{~min}$, rinsed in ethanol, air-dried, and counted in a toluene-based liquid scintillation solution containing $4 \%$ Omnifluor in a Beckman Liquid Scintillation System.

\section{RESULTS}

Figures 1 and 2 show the sedimentation profiles of DNA from $\gamma$-irradiated normal lymphocytes and of $\gamma$-irradiated Down's syndrome lymphocytes, respectively. DNA from normal $\gamma$-irradiated cells sediments, after $\mathrm{l} \mathrm{hr}$ of repair incubation, close to the bottom of the tube, whereas DNA from $\gamma$-irradiated Down's syndrome lymphocytes treated similarly sediments together with DNA from $\gamma$-irradiated cells not exposed to repair incubation. The relative weight average molecular estimations (Table 1) were based on the equation put forward by Palcic and Skarsgard (10):

$$
\mathrm{MW}=\mathrm{Aw}, \mathrm{t} \frac{\sum_{i} \mathrm{Ci}(\mathrm{i}-1 / 2)^{\mathrm{k}}}{\sum_{i} \mathrm{Ci}}
$$

where $i$ is the fraction number counted from the second fraction collected, and $A_{w t}$ and $k$ constants (ibidem) and $C i$ are the percentage total counts.

These results show that although a single-strand DNA breaks repair mechanism is active as is expected, in the normal lymphocytes, such a mechanism seems to be of reduced capacity in the lymphocytes from the three Down's syndrome patients studied.

\section{DISCUSSION}

Previous reports have speculated on the possibility of interpreting chromosome aberrations in terms of damage induced in the

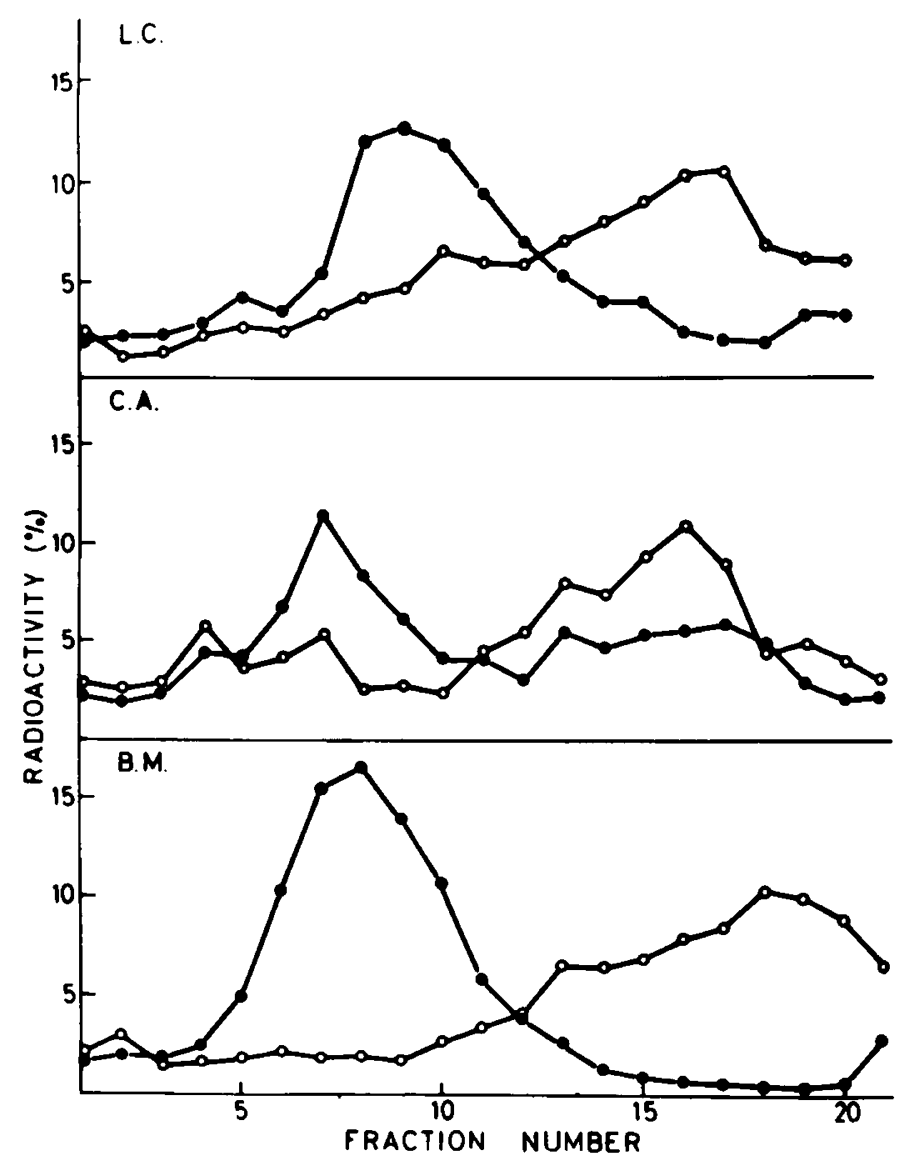

Fig. 1. DNA sedimentation profiles from lymphocytes taken from three normal individuals. Cells were irradiated with $16 \mathrm{krads}$ and incubated $(O)$ at $37^{\circ} \mathrm{C}$ for $1 \mathrm{hr}$ or lysed immediately after irradiation $(\Theta)$.

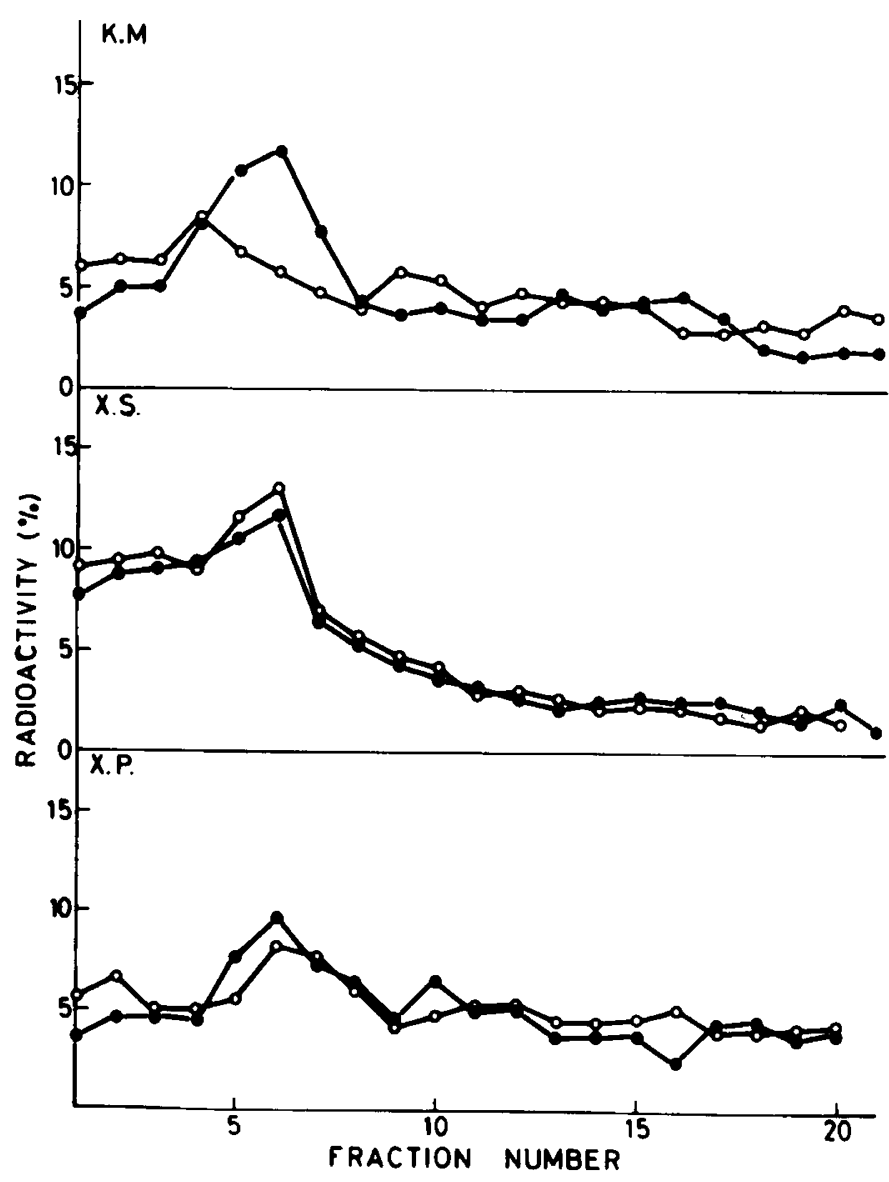

Fig. 2. DNA sedimentation profiles from lymphocytes taken from three Down's syndrome patients. Cells were irradiated with $16 \mathrm{krads}$ and incubated $(O)$ at $37^{\circ} \mathrm{C}$ for $1 \mathrm{hr}$ or lysed immediately aftér irradiation (Q).

Table 1. Ratios of relative weight average molecular weights of DNA from irradiated normal and Down's syndrome lymphocytes

\begin{tabular}{llc}
\hline Case & & $\begin{array}{c}\text { Rel. w.a.MW' of DNA after } \\
\text { l hr incubation }\end{array}$ \\
\cline { 3 - 3 } & & $\begin{array}{c}\text { Rel.w.a.MW' of DNA without } \\
\text { incubation }\end{array}$ \\
\hline Normal & C. A. & 1.4 \\
& L. C. & 1.7 \\
Down's & B. M. & 3.2 \\
syndrome & X. S. & 0.9 \\
& K. M. & 1.0 \\
& X.P. & 1.0 \\
\hline
\end{tabular}

${ }^{1}$ Relative weight average molecular weights.

DNA at the molecular level $(1,4,7)$. This speculation has been investigated, among others, in studies in which cells from humans with inherited disorders classified as chromosome breakage syndromes-ataxia telangiectasia, Fanconi's anemia, and Bloom's syndrome were used $(6,13-15)$. Some people believe that the much higher incidence of chromosomal aberrations induced by $\mathrm{UV}$ or X-rays in xeroderma pigmentosum and ataxia telangiectasia cells, respectively, may be due to unrepaired damage in DNA $(7,16,17)$ and, more specifically, to unrepaired or misrepaired single and double DNA strand breaks. However, no direct experimental data confirm the latter hypothesis.

One human disorder which shows similar characteristics with the above mentioned disorders in respect to chromosome damage is Down's syndrome. This syndrome, occurring with a frequency of about 1.5/1000 newborn infants, causes, in addition to the 
psychomotor retardation and the characteristic physical appearance, a higher risk for leukemia. The most common etiology of Down's syndrome is the result of nondisjunction between an oocyte's two chromosome 21 homologs, an event that seems to occur randomly, but with greater frequency among older women. Cultured lymphocytes from patients with this syndrome are also more sensitive to the production of chromosome dicentrics and rings following $X$-ray exposure (12). This, in conjunction with the results reported here, led us to the speculation that these cells are probably less efficient in repairing certain kinds of damage occurring in their chromosomes. Whether this is also contributing to the higher incidence of leukemia in patients with Down's syndrome will have to be proven.

\section{CONCLUSION}

The present experimental results suggest that the increased frequency of dicentrics and rings observed in human lymphocytes from patients with Down's syndrome is related to the presence of a DNA single-strand break repair mechanism of reduced capacity.

\section{REFERENCES AND NOTES}

1. Bender, M. A., Griggs, H. G., and Bedford, J. S.: Mechanism of chromosomal aberration production, III. Chemicals and ionising radiation. Mutat. Res., 23: 197 (1974).

2. Carrier, W. L., and Setlow, R. B.: Paper strip method for assaying gradient functions containing radioactive macromolecules. Anal. Biochem., 43: 427 (1971).

3. Cleaver, J. E.: Repair processes for photochemical damage in mammalian cells. Adv. Radiat. Biol., 4: 1 (1974).

4. Dubinin, N. P., and Soyfer, V. N.: Chromosome breakage and complete genetic mutation production in molecular terms. Mutat. Res., 8: 353 (1969).

5. Elkind, M. M., and Kamper, C.: Two forms of repair of DNA in mammalian cells following irradiation. Biophys. J., 10: 237 (1970).

6. German, J.: The chromosome breakage syndromes. Birth Defects, 5: 17 (1969).

7. Kihlman, B. A.: Molecular mechanism of chromosome breakage and rejoining. Adv. Cell Mol. Biol., 1: 59 (1971).

8. Lehman, A. R., and Stevens, S.: The production and repair of double strand breaks in cells from normal humans and from patients with ataxia telagniecstasia. Biochim. Biophys. Acta, 474: 49 (1977).

9. Ormerod, M. G., and Stevens, V.: The rejoining of X-ray-induced strand breaks in the DNA of a murine lymphoma cell. Biochim. Biophys. Acta, 232: 72 (1971).

10. Palcic, B., and Skarsgard, L. D.: The effect of oxygen on DNA single-strand breaks produced by ionizing radiation in mammalian cells. Int. J. Radiat. Biol., 21: 417 (1972).

11. Poon, P. K., O'Brien, R. L., and Parker, J. W.: Defective DNA repair in Fanconi's anaemia. Nature (Lond.), 250: 223 (1974).

12. Sasaki, M. S., and Tonomura, A.: Chromosomal radiosensitivity in Down's syndrome. Jpn. J. Hum. Genet., 14: 81 (1969).

13. Sasaki, M. S., Tonomura, A., and Matsubara, S.: Chromosomal constitution and its bearing on the chromosomal radiosensitivity in man. Mutat. Res., 10: 617 (1970).

14. Sawitsky, A., Bloom, D., and German, J.: Chromosomal breakage and acute leukemia in congenital telangiestatic erethma and stunted growth. Ann. Intern. Med., 65: 487 (1966).

15. Swif, M. R., and Hirschorn, K.: Fanconi's anemia. Inherited susceptibility to chromosome breakage in various tissues. Ann. Intern. Med., 65: 496 (1966).

16. Taylor, A. M. R., Metcalfe, J. A., Oxford, J. M., and Harnden, D. G.: Is chromatid type damage in ataxia telangiectasia after irradiation at $\mathbf{G}_{0}$ a consequence of defective repair? Nature (Lond.), 260: 441 (1976).

17. Taylor, A. M. R.: Unrepaired DNA strand breaks in irradiated ataxia telangiectasia lymphocytes suggested from cytogenetic observations. Mutat. Res., 50: 407 (1978).

18. Vincent Jr., R. A., Sheridan III, R. B., and Huang, P. C.: DNA strand breakage repair in ataxia telangiectasia fibroblast-like cells. Mutat. Res., 33: 357 (1975).

19. This work was partially supported by a Grant of the National Research Foundation and the Embeirikeion Foundation of Greece.

20. Requests for reprints should be addressed to: E. G. Sideris, Ph.D., Biology Division, N.R.C. "DEMOKRITOS", Aghia Paraskevi, Athens, Greece.

21. Athanasiou et al: (unpublished data).

22. Received for publication November 6, 1978.

23. Accepted for publication July 12, 1979. 